Головачька C., svitlana-14-10@ukr.net, ORCID ID: 0000-0002-1671-1718, Researcher ID: G-2576-2019, к.е.н., дои., професорка кафедри обліку, контролю, аналізу та оподаткування, Львівський торговельно-економічний університет, м. Львів

Бурденко I., y.burdenko@uabs.sumdu.edu.ua, ORCIDID:0000-0002-5388-2014, к.е.н., дои., доиентка кафедри бухгалтерського обліку та оподаткування, Сумський державний університет, м. Суми

Нагірська К., katya_nagirska@ukr.net, ORCIDID:0000-0002-2792-8162, к.е.н., доц., доцентка кафедри обліку і аудиту, Луцький національний технічний університет, м. Луиььк

Король А., anna.korol.2002.31@gmail.com, бакалавр, Сумський державний університет, м. Суми

\title{
БІХЕВІОРИСТИЧНА МОДЕЛЬ ПРИЙНЯТТЯ РІШЕНЬ У БУХГАЛТЕРСЬКОМУ ОБЛІКУ В УМОВАХ РИЗИКУ ТА НЕВИЗНАЧЕНОСТІ
}

\begin{abstract}
Анотація. Умови невизначеності та ризику стрімко поглинають кожну сферу діяльності, адже модернізований світ - це часті економічні зміни, фінансові кризи і висока конкуренція. Поєднуючи все це у своїй роботі, бухгалтер витрачає максимальний рівень інтелектуальної та емоційної складової, щяо з плином часу може не тільки відобразитися на його зовнішньому стані, а й привести до пригнічення й хвороб, $і$ в результаті до неефективної роботи та прийняття неправильних та неефективних рішень. Біхевіористична модель ставить на меті аналіз усіх психофізіологічних факторів та застосування їх - у разі позитивного впливу на стан працівника, або ж їх мінімізація - у разі, якщо вплив є негативним та шкідливим. Застосування поведінкової моделі допоможе не тільки зберегти значну кількість емоиійних та інтелектуальних втрат облікового працівника, а ще й стабілізувати діяльність підприємства, щзо прямо залежить від його стану. Стаття присвячена дослідженню зв'язку біхевіористичної моделі на прийняття рішень бухгалтером в умовах ризику та невизначеності. Невизначеністю у цъьому аспекті є не співпадіння практичних ситуацій з нормативними документами, при ичьому обліковець повинен самостійно приймати рішення та втілювати його. Бухгалтер аналізує придатність кожного показника: як різні користувачі можуть його сприйняти, яка адекватність показника реальним процесам або очікуванням, який вплив можуть здійснити альтернативні облікові процедури на формування управлінських рішень. Інтелектуальне чи емоційне напруження бухгалтера доволі часто досягає максимального рівня, особливо під час складання звітів та проведення перевірок. Для стабілізації таких ситуаџій можна використовувати моделі біхевіористичної теорії. У статті запропонована найдоречніша з них та представлені шляхи ї̈ практичного застосування, щзо є беззаперечно необхідним у беззбитковому та ефективному функиіонуванні підприємства. Практичне ї̈ застосування може знадобитися при аналізі помилок в роботі бухгалтера та при бажанні позбутися негативних факторів та оптимізувати діяльність підприємства.
\end{abstract}

Ключові слова: поведінкова доктрина, біхевіористична модель, система бухгалтерського обліку, прийняття рішень, умови невизначеності.

Holovatska S.,

svitlana-14-10@ukr.net, ORCIDID:0000-0002-1671-1718,

Researcher ID: G-2576-2019,

Ph.D., Associate Professor, Professor of the Department of Accounting, Control, Analysis and Taxation, Lviv University of Trade and Economics, Lviv 


\title{
Herald of Lviv University of Trade and Economics. Economic Sciences. № 65, 2021
}

Burdenko I.,

y.burdenko@uabs.sumdu.edu.ua,

Ph.D., Associate Professor, Associate Professor of the Department of Accounting and Taxation, Sumy State University, Sumy

Nahirska K., katya_nagirska@ukr.net, ORCIDID: 0000-0002-2792-8162,

Ph.D., Associate Professor, Associate Professor of the Department of Accounting and Audit, Lutsk National Technical University, Lutsk

Korol A., anna.korol.2002.31@gmail.com,

Bachelor's degree student, Sumy State University, Sumy

\section{BEHAVIORISTIC MODEL OF ACCOUNTING DECISION-MAKING UNDER THE CONDITIONS OF RISK AND UNCERTAINTY}

\begin{abstract}
Uncertainty and risk are rapidly absorbing every sphere of activity, as the modernized world is accompanied by frequent economic changes, financial crises and high competition. Combining all this in his work, the accountant spends the maximum level of intellectual and emotional component, which over time can not only affect his appearance, but also lead to depression and diseases, and as a result to inefficient work and making wrong and ineffective decisions. The behavioristic model aims to analyze all psychophysiological factors and apply them - in the case of a positive impact on the condition of the employee, or minimize them - if the impact is negative and harmful. The application of the behavioristic model will help not only to save a significant amount of emotional and intellectual losses of the accountant, but also to stabilize the activities of the enterprise, which directly depends on his condition. The article is devoted to the study of the relationship between the behavioristic model and the decision-making of an accountant under conditions of risk and uncertainty. Uncertainty in this aspect is not the coincidence of practical situations with regulations, in this case, the accountant must make his own decisions and implement them. The accountant analyzes the applicability of each indicator: how different users may perceive it, what is the adequacy of the indicator to real processes or expectations, what is the impact of alternative accounting procedures on the formation of managerial decisions. The intellectual or emotional tension of an accountant often reaches its maximum, especially when compiling reports and conducting audits. Models of behavioristic theory can be used to stabilize such situations. The article offers the most relevant of them and presents ways of its practical application, which is indisputably necessary for the breakeven and efficient operation of the enterprise. Its practical application may be needed when analyzing errors in the work of an accountant and if desired to get rid of negative factors as well as to optimize the company's activities.
\end{abstract}

Key words: behavioral doctrine, behavioristic model, accounting system, decision making, conditions of uncertainty.

JEL Classification: G20, G24, L81, O16

DOI: https://doi.org/10.36477/2522-1205-2021-65-10

Постановка проблеми. На сьогоднішній день процес роботи бухгалтера є значно складнішим та більш різноманітним у порівнянні 3 цим механізмом у соціалістичні часи. На зміну “стандартній” роботі прийшла творча, яка постійна змінюється i потребує самовдосконалення й розвитку. Не слід забувати й про те, що умови невизначеності та ризику стрімко поглинають майже кожну сферу, адже модернізований світ - це часті економічні зміни, фінансові кризи і висока конкуренція. Поєднуючи все це у своїй роботі, бухгалтер витрачає максимальний рівень інтелектуальної та емоційної складової свого здоров'я, що з плином часу може не тільки відобразитися на його зовнішньому стані, а й привести до пригнічення й хвороб і в результаті до неефективної роботи та прийняття неправильних рішень.

Тому біхевіористична модель ставить на меті аналіз усіх психофізіологічних факторів та застосування їх - у разі позитивного впливу на стан працівника, або ж їх мінімізацію - у разі, якщо вплив $є$ негативним та шкідливим. Застосування поведінкової моделі допоможе не тільки зберегти значну кількість емоційних та інтелектуальних втрат обліковця, а ще й стабілізувати діяльність підприємства, що прямо залежить від стану бухгалтера.

Отже, постає проблема у виборі такої моделі 3 урахуванням усіх поведінкових чинників та специфічності роботи бухгалтера та її практичного застосування на підприємстві. 
Аналіз останніх досліджень та публікацій. Дослідженню поведінкової доктрини та її впливу на процес прийняття рішень значну увагу приділяли американські вчені, зокрема Дж. Уотсон у праці "Психологія очима біхевіориста", Е. Торндайк, Е. Брунсвік, Дж, Міллер, Р. Солсо. Пізніше Дж. Міллер, Є. Галантер і К. Прібрам ввели у біхевіористичну теорію принцип зворотного зв'язку. Проблемами досліджень біхевіористики для облікової теорії займалися К. Девине, Д. Бирнберг i М. Шилдс, що ввели поняття, відоме як “біхевіористичний бухгалтерський облік". Серед інших дослідників, праці яких присвячені розгляду проблем облікової теорії та біхевіористичного підходу, Я. В. Соколов. Серед вітчизняних науковців можна виділити праці Р. Романів [7], О. Бондаренко [1], П. Куцика [3. 12], І. Садовської [13], Ю. Слюсаренко, М. Козлова [2. 11] та ін.

Постановка завдання. Метою статті $є$ детальне дослідження біхевіористичних моделей, їх особливостей та відповідно до цього - визначення найдоречнішої з них для системи бухгалтерського обліку.

Виклад основного матеріалу дослідження. Класичну та базову формулу біхевіористичної теорії навів Дж. Уотсон у своій праці "Психологія очима біхевіориста" (1913 рік) (рис. 1). Він відстоював тезу, що дослідження психіки повинні зводитися до вивчення поведінки через аналіз зв'язків між стимулами i, що виникають на їх основі, реакціями (принцип "суміжності" (contiguity) стимулу i реакції) [1].

Інтерпретуємо сутність цієї формули через застосування у системі бухгалтерського обліку, а саме: будь-який стимул (внутрішній чи зовнішній) визначає певну модель поведінки бухгалтера, основи формування його професійного судження.

На довгі десятиліття формула "стимул-реакція" (S-R) стала розглядатися як універсальна основа для інтерпретації поведінки. Сформульовані Уотсоном принципи отримали дуже велике поширення і подальший різноплановий розвиток [1].

Значний внесок у розвиток біхевіористичної теорії зробив Е. Торндайк, який доповнив цю формулу складовою “підкріплення". Тобто формула біхевіоризму за Торндайком мала вигляд, як на рис. 2.

Зауважимо, що вагомою складовою класичної формули Дж. Уотсона стало “підкріплення”, відповідно до якого відбуватиметься дія чи формуватиметься думка.

Спираючись на розуміння механізму поведінки як зв'язку стимулу (документу) і реакції (реагування бухгалтера), прибічники застосування біхевіоризму зробили висновок про те, що робота бухгалтера попадає під чітку стандартизацію 3 набором заданих рішень і правом вибору, тобто професійним судженням. Як зазначає А. А. Солоненко, це дозволило застосувати принципи біхевіоризму в фінансовому обліку в межах представлення звітних даних у більш зручному вигляді для різних груп користувачів [5].

Потрібно підкреслити, що бухгалтер аналізуе придатність кожного показника: як різні користувачі можуть його сприйняти, яка адекватність показника реальним процесам або очікуванням, який вплив можуть здійснити альтернативні бухгалтерські процедури на формування управлінських рішень. У зв'язку зі складовими інформаційної схеми (вхід, обробка, вихід) виділяють три оцінки кожного проміжного етапу, який проходить бухгалтерська інформація. На вході беруть до уваги: обсяг даних, їх змістову характеристику, спосіб представлення, характеристику завдання; при обробці особистісні характеристики бухгалтерів та їх оточення, що здійснюють вплив на їх рішення; на виході - об'єм вихідних даних, їх змістову характеристику, самооцінку рішень бухгалтера [6].

Для оцінки ефективності прийняття рішень бухгалтером Я. В. Соколов пропонує застосовувати три моделі:

- лінзи Брунсвіка (імовірнісний функціоналізм);

- стохастичну;

- когнітивну.

Аналіз та порівняння цих моделей здійснено у таблиці 1.

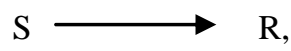

$$
\begin{aligned}
& \text { де } \mathrm{S} \text { - стимул; } \\
& \mathrm{R} \text { - дія. }
\end{aligned}
$$

Рис. 1. Формула біхевіористичної теорії за Дж.Уотсоном Джерело: сформоване на основі [2,3]

де $\mathrm{S}$ - стимул;
$\mathrm{T}$ - підкріплення;
$\mathrm{R}$ - дія.

Рис. 2. Формула біхевіоризму за Торндайком 
Herald of Lviv University of Trade and Economics. Economic Sciences. № 65, 2021

Джерело: сформоване на основі [3,4]

Таблиия 1

Порівняння моделей поведінкової доктрини

\begin{tabular}{|c|c|c|c|c|}
\hline \multirow{2}{*}{$\begin{array}{c}\text { Критерій порів- } \\
\text { няння }\end{array}$} & \multicolumn{4}{|c|}{ Назва моделі } \\
\hline & Лінзова & Стохастична & Когн1 & ивна \\
\hline $\begin{array}{l}\text { Вчені, які займа- } \\
\text { лися розробкою, } \\
\text { рік }\end{array}$ & Е. Брунсвік (1947) & $\begin{array}{l}\text { Дж, Міллер і Н. Хом- } \\
\text { ський - “Психолінгві- } \\
\text { стика другого поко- } \\
\text { ління" (1963) }\end{array}$ & $\begin{array}{l}\text { Дж. Міллер, С. } \\
\text { Галантер і К. Прі- } \\
\text { брам - “Плани і } \\
\text { структура поведі- } \\
\text { нки” (1965) }\end{array}$ & $\begin{array}{l}\text { Р. Солсо - “Ког- } \\
\text { нітивна психоло- } \\
\text { гія" (2006) }\end{array}$ \\
\hline $\begin{array}{l}\text { Основні поло- } \\
\text { ження }\end{array}$ & $\begin{array}{l}\text { Кожен індивід по- } \\
\text { різному “читає" } \\
\text { інформацію, яка } \\
\text { по-різному впливає } \\
\text { на індивіда }\end{array}$ & $\begin{array}{l}\text { “Зародження” су- } \\
\text { дження грунтується } \\
\text { на теорії ймовірності } \\
\text { та залежить від вже } \\
\text { отриманого досвіду. В } \\
\text { основу покладений } \\
\text { байєсовський підхід }\end{array}$ & $\begin{array}{l}\text { Заміна класичної } \\
\text { формули біхевіо- } \\
\text { ризму на “Т-О-Т- } \\
\text { Е” (“'Test- } \\
\text { Operate-Test- } \\
\text { Exit” - проба- } \\
\text { операція-проба-- } \\
\text { вихід), вивчає } \\
\text { відношення між } \\
\text { стимулом і реак- } \\
\text { цією на основі } \\
\text { зворотного } \\
\text { зв’язку, зв’язок } \\
\text { образу й плану }\end{array}$ & $\begin{array}{l}\text { Спочатку } \\
\text { з’являється сти- } \\
\text { мул, потім його } \\
\text { “розпізнає” сен- } \\
\text { сорна система, } \\
\text { зберігає його в } \\
\text { пам'яті та реагує } \\
\text { на нього, тобто } \\
\text { вивчає те, } \\
\text { як індивідууми } \\
\text { отримують ін- } \\
\text { формацію... як } \\
\text { вона перетворю- } \\
\text { ється у знання і } \\
\text { як ці знання } \\
\text { впливають на } \\
\text { поведінку, тобто } \\
\text { охоплює весь } \\
\text { діапазон } \\
\text { психологічного } \\
\text { процесу [6, с. 5] }\end{array}$ \\
\hline Недоліки & & $\begin{array}{l}\text { Ситуації не є детермі- } \\
\text { нованими, а отже, й } \\
\text { наявність складових } \\
\text { більше покладається } \\
\text { на теорію ймовірності }\end{array}$ & $\begin{array}{l}\text { Відходження від } \\
\text { основних поло- } \\
\text { жень поведінкової } \\
\text { теорії }\end{array}$ & $\begin{array}{l}\text { Головною скла- } \\
\text { довою } є \text { пам’ять }\end{array}$ \\
\hline Переваги & $\begin{array}{l}\text { Індивідуальність } \\
\text { людини є найголо- } \\
\text { внішим при визна- } \\
\text { ченні ефекту }\end{array}$ & $\begin{array}{l}\text { Поєднання знань та } \\
\text { досвіду }\end{array}$ & $\begin{array}{l}\text { "Внутрішні” сти- } \\
\text { мули більш вагомі } \\
\text { за "зовнішні" }\end{array}$ & $\begin{array}{l}\text { Охоплює всю } \\
\text { систему психо- } \\
\text { логічного проце- } \\
\text { су прийняття } \\
\text { рішень }\end{array}$ \\
\hline
\end{tabular}

Джерело: власна розробка авторів

Підсумовуючи дані, які наведені у таблиці, підкреслимо особливості розглянутих моделей.

Що стосується лінзової моделі Брунсвіка, то основною ідеєю та найголовнішою перевагою $\epsilon$ питання індивідуальності, тобто на кожен невизначений процес, який відбувається у навколишньому середовищі, існує суб'єктивний аналіз та відповідна особлива реакція.

Розглядаючи стохастичну модель, якій особливе місце приділено у праці Дж. Міллера і Н. Хомського - "Психолінгвістика другого покоління" (1963), можна стверджувати, що основною ідеєю у цій системі $є$ певна ймовірність та "хаотичність" ситуацій. На нашу думку, такий підхід можна використовувати для біхевіористичного спрямування у бухгалтерській роботі, проте все ж таки він певним чином $є$ недетермінованим та потребує значного втручання математичного аналізу для обробки такого масиву інформації.

Якщо розглядати когнітивну модель, то можна прослідкувати, як поділилися погляди вчених на цю ситуацію. Дж. Міллер, С. Галантер і К. Прібрам у своїй праці "Плани і структура поведінки" (1965) вивчали даний механізм як реакцію стимулу та дії на когнітивні функції людини, що не відповідає формулі біхевіоризму та певним чином відходить від головної ідеї поведінкової доктрини. Тому, як ми вважаємо, ця модель не є релевантною для біхевіористичного обліку. Проте, розглядаючи вчення Р. Солсо про когнітивний механізм, можна погодитися 3 тим, що аналіз впливу певних факторів на прийняття людиною рішень повинен відбуватися 3 урахуванням усього спектра психофізичних та навколишніх даних. Та все ж таки цю модель не зо- 
всім доречно використовувати у нашому випадку, адже головним елементом у цій ситуації є зв'язок короткострокової, довгострокової пам'яті зі стимулом та відповідною реакцією, що також відходить від класичної системи біхевіористичної доктрини.

На нашу думку, найдоречнішою моделлю, яка дозволяє бухгалтеру приймати релевантне рішення в умовах невизначеності при отриманні масиву інформації, є лінзова модель Брунсвіка, яка базується на накопиченому досвіді і знаннях.

Як вже зазначалося раніше, саме лінзова модель Брунсвіка (модель імовірнісного функціоналізму) підходить для застосування її основних принципів у роботі бухгалтера, спираючись на певні положення біхевіористичної доктрини. Проте, чи $\epsilon$ це застосування ефективним та як саме воно відбувається, потрібно детально проаналізувати.

Навколишній світ, бізнес $\epsilon$ непередбачуваними та ризикованими, в яких знання чи сприйняття ситуації, закономірного характеру є складною системою поведінкового механізму, а їх аналіз та усвідомлення здійснюються суб'єктивно, спираючись на досвід та знання. Для того, щоб дослідити та дати наукове окреслення процесу сприйняття навколишніх факторів та на цьому підгрунті винесення певних рішень, Е. Брунсвік створив модель лінзи та запропонував використовувати іiі при розгляді різних стадій цього складного процесу.
Потрібно підкреслити, що сама назва моделі прямо описує іiі основні положення. Адже, як i звичайна лінза охоплює розсіяне світло i зосереджується на одній точці на сітківці, так і сенсорна система людини “відфільтровує" потік навколишніх факторів. Як уже зазначалося, не кожен фактор є “корисним” для сприймаючого, тому центральну позицію в цій моделі у процесі сприйняття займають саме доцільні сигнали.

Головною ідеєю лінзової моделі є індивідуальність кожної людини, тобто зовнішні стимули сприймаються суб'єктивно та прямо залежать від прожитого в минулому досвіду та теперішніх почуттів.

Для більш детального розгляду моделі Брунсвіка пропонуємо розглянути іiі схематично, за допомогою рисунку 3 , який наведений нижче.

Потрібно додати, що ця модель може використовуватися не тільки з точки зору психології, а й у таких прикладних науках, як математика, авіабудування, морська навігація та у багатьох інших. Саме тому доцільно розглянути даний механізм на прикладі бухгалтерського обліку, а саме: яким чином впливають зовнішні чинники на прийняття рішень бухгалтера.

Пропонуємо розглянути це на прикладі прийняття такого рішення бухгалтером, як пропозиції щодо фінансової оптимізації підприємства (рис. 4).

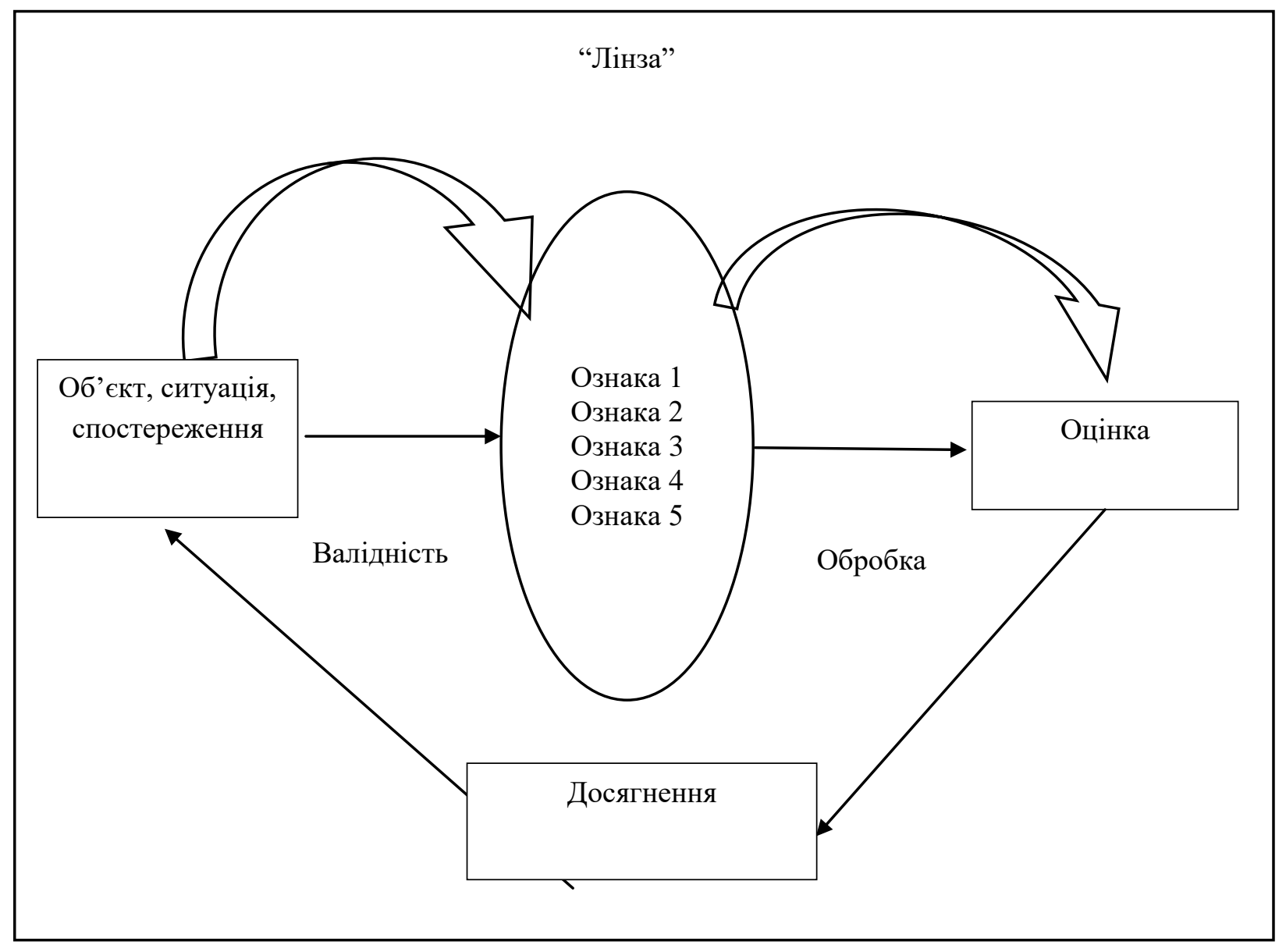

Джерело: створено на основі [8]

Рис. 3. Лінзова модель Брунсвіка 


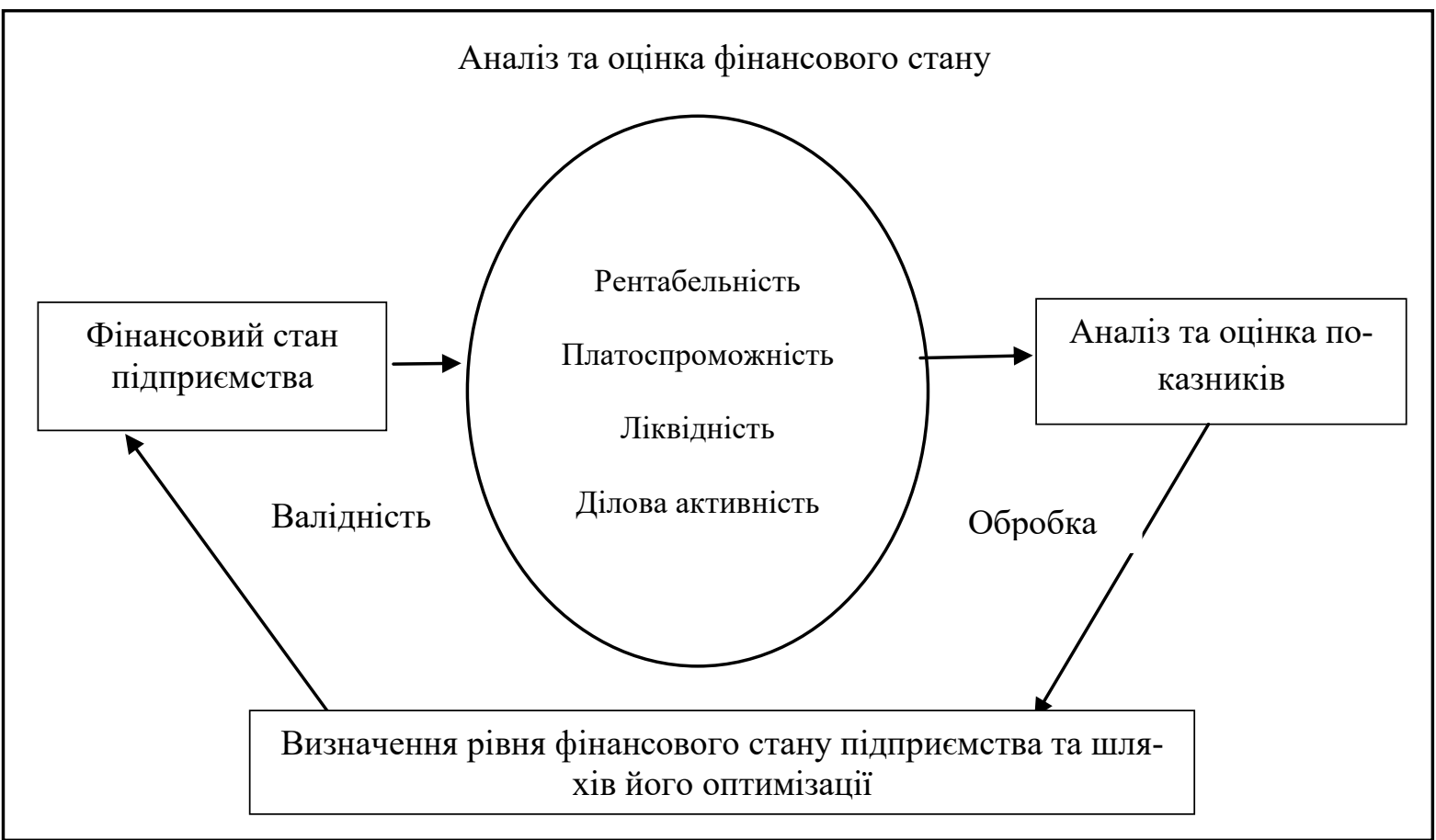

Рис. 4. Приклад використання лінзової моделі Брунсвіка при прийнятті рішення щодо пропозиції 3 Джерело: власна розробка авторів покращення фінансового стану підприсмства

Потрібно додати, що модель Брунсвіка допомагає не тільки виявити вплив зовнішніх сигналів на механізм прийняття рішень, а також нейтралізувати такий фактор, як “порушення закономірного характеру”. Цей чинник передбачає такі ситуації, коли при знайомих та вже колись минулих обставинах можуть виникати певні проблеми зі спотворенням їх сприйняття. Е. Брунсвік запропонував використовувати екологічну валідність задля правильного, хоч й імовірнісного, відношення реакції сприймаючого до сигналів навколишнього середовища. В іiі основу покладено певний “закон”, відповідно до якого інтерпретація інформації буде правильною у тому випадку, коли доцільність проксимального стимулу - властивість сприйняття ознаки дистального стимулу, - буде відповідати характеристикам дистального стимулу - об'єкта в матеріальному окресленні. Не менш важливим $є$ той факт, що для адекватного сприйняття зовнішніх сигналів необхідною умовою $є$ визначення головних, “істинних" стимулів із урахуванням змін проксимальних ознак, які впливають на сенсорну систему, що, у свою чергу, становить прямий та беззаперечний вплив на прийняття рішення.

На прикладі бухгалтерської роботи можна прослідкувати такий зв'язок наступним чином: для того, щоб з'ясувати залежність між реакцією облікового працівника на таку ризикову ситуацію, як перевірка, необхідно визначити дистальний та проксимальний стимули. Дистальним у цьому випадку є факт самої перевірки, а проксимальним загрози, які вона може понести для бухгалтера. Тобто, відштовхуючись від того, як другий чинник сприймається обліковцем, можна встановити, яка саме реакція буде відтворена, та, як наслідок, - яке рішення буде прийнято.

Висновки і перспективи подальших досліджень у даному напрямі. У ході дослідження був проведений детальний аналіз біхевіористичних моделей і доведена їх необхідність застосування для оптимізації роботи бухгалтера. Пропонуємо брати до уваги лінзову модель Брунсвіка - найбільш доречну з урахуванням головних положень поведінкової доктрини та специфіки бухгалтерського обліку.

На питання, чи є ця модель ефективною при визначенні залежності рішення бухгалтера від зовнішніх факторів, $є$ чітка відповідь - так. Адже, на нашу думку, визначення впливу “абстрактних" чинників на сприйняття чіткої ситуації $є$ проявом індивідуалізму, що є першочерговим при вивченні в поведінковій доктрині реакції та ऑї результату створення професійного судження та прийняття відповідного управлінського рішення.

Практичне іï застосування може знадобитися при аналізі помилок у роботі бухгалтера, при його постійному та зростаючому емоційному чи інтелектуальному виснаженні, при бажанні позбутися цих факторів та оптимізувати діяльність підприємства.

\section{ЛІТЕРАТУРА}

1. Бондаренко О. В., Слюсаренко Ю. Л. Біхевіоризм від Джона Б. Уотсона до Е. Томлена. Наукові горизонти. 2019. №2 (75). С. 80-83.

2. Козлова Я. Джон Бродес Уотсон: веб-блог. URL: https://ru.scribd.com/presentation/ 509014133/ Джон-Бродес-Уотсон. 
3. Куцик П. О. Концепція уніфікованої системи обліку і звітності в корпоративному управлінні : монографія. Львів : ЛТЕУ, 2017. 408 с.

4. Филлин С. Концепции современного естествознания: конспект лекций. URL: https://www.gumer.info/ bibliotek_Buks/Science/filin/ 10.php.

5. Закон ефекту Едварда Торндайка. Блог 3 філософії та психології. Статті про різні аспекти психології людини. URL: https://ua.sainteanastasie.org/articles/psicologia/la-ley-del-efecto-deedward-thorndike.html.

6. Солоненко А. А. Поведенческий бухгалтерский учёт: реалии и перспективы. Вестник АГТУ. 2015. № 1. С. 89-99.

7. Романів Р. Апперцепція інформації в біхевіористичній теорії бухгалтерського обліку: критика сучасних підходів. Вісник Тернопільського національного економічного університету. 2018. № 2. С. 1-8.

8. Русай В. Обробка зверху вниз. Байєсовський підхід: веб-блог. URL: https://uk.larafornm.com/top-down-processing18\#menu-9.

9. Смолова Л. В. Экологическая валидность. Москва : Юрайт, 2019. 882 с.

10. Капличний С. Что такое фрейминг или как формулировки влияют на наш выбор: веб-блог. URL: https://biz.mann-ivanov-ferber.ru/2017/12/13/ chto-takoe-frejming-ili-kak-formulirovki-vliyayut-nanash-vybor/.

11. Козлова М. О. Влияние психологических и лингвистических аспектов на организацию бухгалтерского учета. Проблемы. Мнения. Решения. Вісник Житомирського державного технологічного університету. 2013. №24. С. 17-27.

12. Institutionalization of accounting and auditing services in Ukraine: genesis, evaluation, analysis / O. Antoniuk, P. Kutsyk, I. Brodska, O. Kolesnikova, N. Struk. Independent Journal of Management \& Production. 2021. 12 (3). S. 123-137.

13. Semenyshena N., Khorunzhak N., Sadovska I. Evaluation of the adaptability of scientific theories for the development of accounting institute. Intellectual economics. 2020. 14 (1). P. 113-129.

\section{REFERENCES}

1. Bondarenko, O. V. and Sljusarenko, Ju. L. (2019), Bikhevioryzm vid Dzhona B. Uotsona do E. Tomlena, Naukovi ghoryzonty, №2 (75), s. 80-83.

2. Kozlova Ja. Dzhon Brodes Uotson: veb-blogh, available at: https://ru.scribd.com/presentation/ 509014133/Dzhon-Brodes-Uotson.
3. Kutsyk, P. O. (2017), Kontseptsiya unifikovanoyi systemy obliku i zvitnosti v korporatyvnomu upravlinni : monohrafiya, LTEU, L'viv, $408 \mathrm{~s}$.

4. Fyllyn S. Koncepcyy sovremennogho estestvoznanyja: konspekt lekcij, available at: https://www.gumer.info/bibliotek_Buks/Science/filin/ 10.php.

5. Zakon efektu Edvarda Torndajka. Blogh z filosofiji ta psykhologhiji. Statti pro rizni aspekty psykhologhiji ljudyny, available at: https://ua.sainteanastasie.org/articles/psicologia/la-ley-del-efecto-deedward-thorndike.html.

6. Solonenko, A. A. (2015), Povedencheskyj bukhghaltersjkyj uchët: realyy y perspektyvы, Vestnyk AGhTU, № 1, s. 89-99.

7. Romaniv R. (2018), Appercepcija informaciji $\mathrm{v}$ bikheviorystychnij teoriji bukhghaltersjkogho obliku: krytyka suchasnykh pidkhodiv, Visnyk Ternopiljsjkogho nacionaljnogho ekonomichnogho universytetu, № 2, s. 1-8.

8. Rusaj V. Obrobka zverkhu vnyz. Bajjesovsjkyj pidkhid: veb-blogh, available at: https://uk.larafornm.com/top-down-processing18\#menu-9.

9. Smolova, L. V. (2019), Эkologhycheskaja valydnostj, Jurajt, Moskva, $882 \mathrm{~s}$.

10. Kaplychnyj S. Chto takoe frejmyngh yly kak formulyrovky vlyjajut na nash vыbor: veb-blogh, available ar: https://biz.mann-ivanovferber.ru/2017/12/13/chto-takoe-frejming-ili-kakformulirovki-vliyayut-na-nash-vybor/.

11. Kozlova, M. O. (2013), Vlyjanye psykhologhycheskykh y lynghvystycheskykh aspektov na orghanyzacyju bukhghalterskogho ucheta. Problemы. Mnenyja. Reshenyja, Visnyk Zhytomyrsjkogho derzhavnogho tekhnologhichnogho universytetu, № 24, s. 17-27.

12. Institutionalization of accounting and auditing services in Ukraine: genesis, evaluation, analysis / O. Antoniuk, P. Kutsyk, I. Brodska, O. Kolesnikova, N. Struk (2021), Independent Journal of Management \& Production, 12 (3), s. 123-137.

13. Semenyshena N., Khorunzhak N. and Sadovska I. (2020), Evaluation of the adaptability of scientific theories for the development of accounting institute. Intellectual Economics, 14 (1), p. 113-129.

Стаття надійила до редакиіï 12 грудня 2021 року 